\title{
ANALIZA STANIŠNIH USLOVA I OPTIMIRANJE UZGOJNIH MJERA U PANJAČI BUKVE NA LOKALITETU "MUSIĆI" KOD SARAJEVA
}

\section{Analysis of habitat and structural characteristics and optimization of silvicultural measures in coppice beech forest at the site "Musići" near Sarajevo}

\author{
Ćemal Višnjić ${ }^{1}$, Faruk Mekić ${ }^{1}$, Sead Vojniković ${ }^{1}$, Besim Balić$^{1}$, Sead Ivojević ${ }^{1}$
}

\begin{abstract}
Coppice beech forests in $\mathrm{BiH}$ covers an area of 351,000 ha which is about $13 \%$ of the total area of forests and forest land. Production capacity under these forest habitats are not fully utilized and it is necessary silvicultural operations to improve their condition. This work investigates the structural characteristics of the habitat and coppice beech forest before and after thinning the example Musići tree coppice forests at the site near Sarajevo. The 60 year coppice beech forest were set up two experimental plots on which they are carried out in two ways thinning: selective thinning and selective thinning with cuting residual trees from stump. Habitat and structural characteristics have a decisive importance in choosing the way of translation tree coppice forests in the form of higher breeding. Thinning need to accommodate the situation in which the tree coppice forests located. Selective thinning with cuting residual trees in the lower tree floor should be given a basis for future measures in the care coppice beech.
\end{abstract}

$\underline{\text { Key words: }}$ becch coppice, structure, site conditions, high forest, selective thinning

\section{Izvod}

Panjače bukve u BiH zauzimaju površinu od 351.000 hektara, što je oko $13 \%$ od ukupne površine šuma i šumskog zemljišta. Proizvodne mogućnosti ovih šuma nisu potpuno iskorištene pa je potrebno uzgojnim zahvatima poboljšati njihovo stanje. U ovom radu analizirane su stanišne karakteristike panjače bukve na lokalitetu "Musići" kod Sarajeva. U 60-godišnjoj panjači bukve postavljene su (u proljeće 2007. godine) dvije eksperimentalne plohe na kojim su provedena dva načina prorjeđivanja i to: selektivna prorjeda i selektivna prorjeda sa čišćenjem zaostalih i loših izbojaka sa panja. Stanišne i strukturne karakteristike imaju odlučujući značaj kod odabira načina prorjeđivanja panjača u cilju prevođenja u viši uzgojni oblik. Prorjedu treba prilagoditi

\footnotetext{
${ }^{1}$ Šumarski fakultet Univerziteta u Sarajevu - Faculty of Forestry University of Sarajevo
} 
stanju u kojem se panjača nalazi. Selektivna prorjeda uz uklananje zaostalih i loših izbojaka sa panja treba biti osnov za buduće mjere njege u mlađim panjačama bukve.

Ključne rïeči: bukova panjača, struktura, stanišni uslovi, visoka šuma, selektivna prorjeda

\section{Uvod - Introduction}

Od ukupne površine $\mathrm{BiH}$ na šume i šumska zemljišta otpada 2.701.000 hektara, od toga na visoke šume $46,9 \%$, na panjače $34,3 \%$, na neobrasle površine sposobne za pošumljavanje $14,7 \%$ i na neobrasla neproduktivna tla 4,1 \%. Od ukupne površine panjača, koja iznosi 927.000 hektara, na panjače bukve otpada 351.000 hektara $(38,9 \%)$, hrasta kitnjaka 218.000 hektara $(23,5 \%)$, termofilnih hrastova 316.000 hektara $(34,1 \%)$ i panjače ostalih vrsta 42.000 hektara (4,5\%) (MATIĆ I DR., 1971, PINTARIĆ, 2002).

Panjače bukve se uglavnom nalaze na najproduktivnijim tlima. U prošlosti su bile vrlo vrijedne visoke šume kojim se u gospodarenju nije poklanjala pažnja, te su nekontrolisanom sječom pretvorene u nekvalitetne i slabo produktivne panjače (PINTARIĆ, 2002). Sa prevođenjem panjača u viši uzgojni oblik počelo se početkom prošlog stoljeća. Najveći zamah u melioraciji bukovih panjača bio je od 1959. do 1960. godine kada je vršeno čišćenje i podsijavanje sjemena jele na većim ili manjim površinama. Uspjeh je bio različit, a radovi nisu nastavljeni tako da je i željeni cilj izostao (STOJANOVIĆ I DR., 1986 a i 1986 b). Problemom prevođenja panjača bukve u viši uzgojni oblik bavili su se brojni istraživači (PATAKY, 1956, 1960; ALIKALFIĆ, 1998, STOJANOVIĆ, I DR., 1986 a, PINTARIĆ, 2002, KRSTIĆ, 2004). U svim istraživanjima postupci prevođenja panjača u viši uzgojni oblik se zasnivaju na indirektnoj ili direktnoj konverziji. Indirektnom konverzijom se postepeno mjerama njege prorjedama, panjača dovodi u takvo stanje da obilno plodonosi. Zatim se oplodnom sječom vrši podmlađivanje kada se razvija visoka šuma. Direktnom konverzijom se sjeku sva stabla panjače, nakon čega se vrši pošumljavanje istom vrstom (rekonstrukcija) ili izmjenom vrste (supstitucija).

MATIĆ I DR. (2003) navode da bi bila velika greška kada bi se panjače bukve prevodile u visoku šumu direktnom konverzijom uz sadnju neke četinarske vrste. Četinarske vrste $u$ takvim uslovima ne mogu izdržati konkurenciju autohtonih lišćarskih vrsta koje bi se ubrzo pojavile na tom staništu. Matić predlaže, u mlađim sastojinama mjere njege prorjedom koja bi se provodila po sistemu regularne prorjede za visoke bukove šume, dok bi se starije bukove panjače prevodile u viši uzgojni oblik prirodnim podmlađivanjem putem oplodne sječe. Ukoliko iz bilo kojeg razloga izostane urod sjemena, podmlađivanje bi trebalo obaviti sadnjom sadnica ili podsijavanjem sjemena držeći se opštih načela oplodne sječe. PINTARIć (2002) ukazuje na značaj selektivne prorjede i odabiranja stabala budućnosti s ciljem dobivanja vrijednog drveta, a kasnije kada stabla dosegnu zrelost, prema njegovom mišljenju treba izvršiti podmlađivanje sastojine oplodnom sječom. KRSTIĆ I DR. (2004) predlažu indirektnu konverziju kvalitetnijih panjača u viši uzgojni oblik, dok na tlima čiji 
proizvodni potencijal nije u potpunosti iskorišten predlažu direktnu konverziju izmjenom vrste.

Nakon provedenog uzgojnog zahvata potrebno je da prođe određeno vrijeme kako bi se mogli sagledati njegovi efekti. Najčešće je to period od 5 do 10 godina. Međutim, tek na kraju produkcionog perioda mogu se utvrditi stvarni efekti primijenjenih uzgojnih mjera po kvalitetu i količini proizvedene drvne mase. Zbog potrebe dobivanja bržih informacija o uticaju različitih načina prorjeđivanja na budući razvoj sastojine, zadnjih desetljeća su razvijeni mnogobrojni softverski programi pomoću kojih je moguće simulirati budući razvoj sastojine (KRSTIĆ, 2003; NAGEL, 2006.).

U ovom radu su analizirani stanišni, strukturni i kvalitetni pokazatelji panjače bukve. U panjači bukve homogenih stanišnih uvjeta postavljene su dvije eksperimentalne plohe na kojim su provedene uzgojne mjere prorjeđivanja. Na prvoj eksperimentalnoj plohi provedena je Šedelinova (Schädelin) selektivna prorjeda. Na drugoj eksperimentalnoj površini provedena je selektivna prorjeda sa uklanjanjem zaostalih i loših izbojaka sa panja. Analiziran je uticaj načina prorjeđivanja na stanje panjače nakon prorjede u pogledu njenog intenziteta po broju stabala, temeljnici i zalihi drvne mase. Pored toga, pomoću softverskog programa BWINPro, izrađen je model rasta i razvoja panjače bukve prije i nakon provedenih prorjeda.

\section{Materijal i metode rada - Material and Methods}

Istraživanja su provedena na lokalitetu „Musići” kod Sarajeva. Unutar 60godišnje panjače bukve na kiselo smeđim zemljištima perm-karbonskih formacija, postavljene su dvije eksperimentalne plohe kvadratnog oblika sa dužinom stranice kvadrata od $50 \mathrm{~m}$. Plohe se nalaze na oko $600 \mathrm{~m}$ nv, eksponirane su prema sjeveru i imaju približno iste stanišne strukturne karakteristike. Plohe su obilježene a svako stablo unutar plohe je numerisano. Za svako stablo je utvrđena pripadanost vrsti drveća i porijeklo. Na plohama je izvršen potpuni premjer i to: prsnog prečnika, visine stabla, dužine krošnje, utvrđena je pripadnost Kraftovoj klasi, zdravstveno stanje i broj izbojaka iz jednog panja. Pored toga, ortogonalnom metodom određen je položaj svakog stabla unutar plohe.

Stanje prirodnog podmlatka je utvrđeno na probnim krugovima radijusa $3 \mathrm{~m}$. Na jednoj plohi postavljeno je po 16 krugova za prebrojavanje prirodnog podmlatka.

$\mathrm{Na}$ plohama su provedena dva načina prorjeđivanja. Na plohi I je provedena selektivna prorjeda po SCHAEDELINU (1942). Izvršeno je odabiranje stabala budućnosti, a uklonjena su samo ona koja smetaju odabranim. Na plohi nisu doznačena stabla sjemenog porijekla, dok su svi šubarci doznačeni.

Na plohi II je provedena selektivna prorjeda uz reduciranje broja zaostalih i loših izbojaka sa panja. Na panju je ostavljeno jedno do dva najkvalitetnija stabla. Stabla sjemenog porijekla i šubarci nisu doznačeni. 


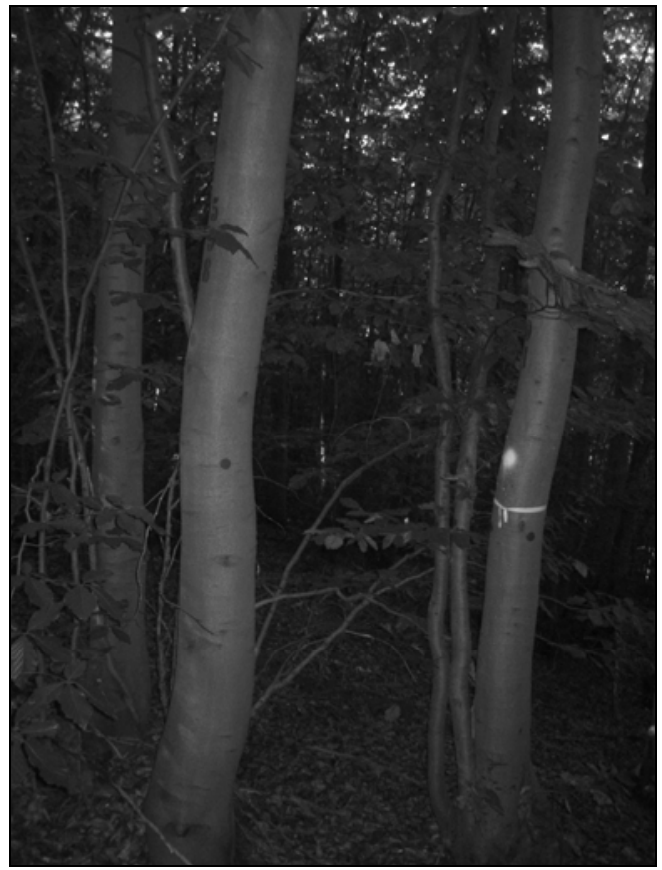

Slika 1. Ploha I, selektivna prorjeda, odabiranje i pomaganje stabala budućnosti Foto 1. Plot I, selective thinning, selection and helping of $Z$ - trees

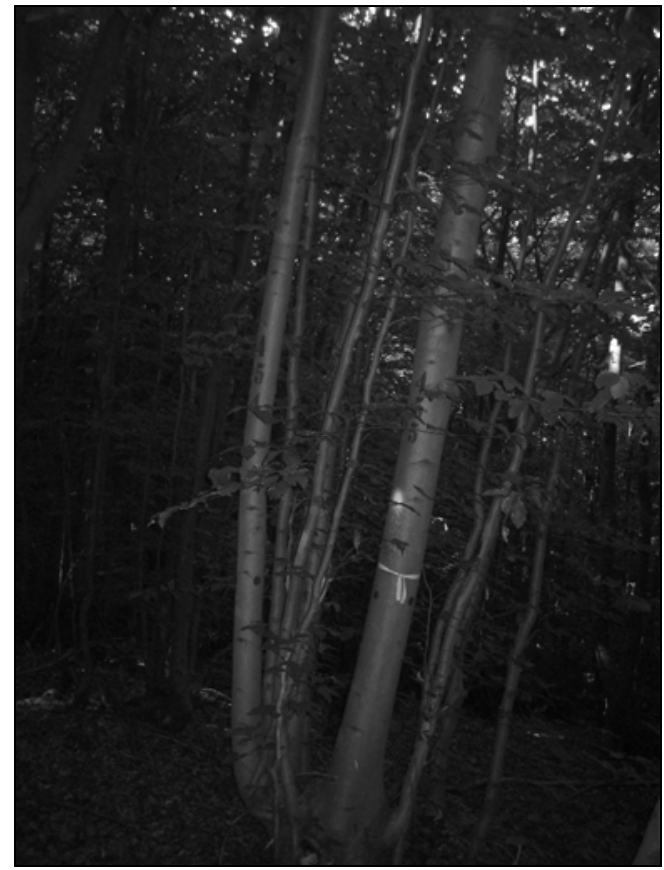

Slika 2. Ploha II, selektivna prorjeda uz reduciranje zaostalih i loših izbojaka na panju Foto 2. Plot II, selctive thinning with cating of bad stam from stamp

Podaci prikupljeni tokom terenskih istraživanja su obrađivani u softverskim aplikacijama Exel 2007, Statistika 9, i BWINPro.

\section{Rezultati rada - Results}

\section{Stanišne i strukturne karakteristike}

Mnogobrojna istraživanja ukazuju da postoji veliki broj tipova panjača bukve koji se razlikuju kako po vegetacijskim karakteristikama tako i po proizvodnosti (STOJANOVIĆ I DR. 1986 a; PINTARIĆ, 2002; KRSTIĆ I DR., 2004; KoRIČIĆ, 2006). Međutim, i unutar istog tipa panjače, čak i unutar jedne sastojine, postoje mnogobrojna obilježja koja jako variraju i u potpunosti određuju uzgojne postupke koji imaju za cilj konverziju u visoke šume. Od tih obilježja, prije svega, potrebno je poznavati: 


\section{Starost panjače}

Panjače bukve su nastale čistom sječom visokih šuma pa su izbojci iz panja približno iste starosti, što je karakteristično za jednodobne šume. S obzirom na starost panjače mogu se definirati i uzgojni postupci. Tako MATIĆ (1987) predlaže u panjačama bukve mlađim od 60 godina provođenje prorjeda kao uzgojnih mjera, dok za panjače starije od 60 godina predlaže uzgojne radove na obnovi oplodnom sječom. KRSTIĆ I DR, (2005) predlažu granicu od 80 godina starosti iznad koje bi se otpočinjalo sa obnovom oplodnom sječom. Mlađe panjače dobrog kvalitetnog sastava bi trebalo prorjeđivati, dok bi panjače lošeg kvaliteta trebalo direktnom konverzijom prevoditi u visoke šume. Kako proizvodne mogućnosti staništa panjača nisu dovoljno iskorištene, opravdano je ranije početi sa obnavljanjem ovih šuma, posebno ako su lošeg kvalitetnog sastava. Panjača bukve na lokalitetu „Musići“ je stara oko 60 godina i dobrog je kvalitetnog sastava te bi u narednom 20-godišnjem periodu trebalo otpočeti sa podmlađivanjem primjenom oplodne sječe.

\section{Generacija panja}

Panjače razvijaju stabla - izbojke iz panja. Izbojci koji se pojave nakon sječe visoke šume pripadaju prvoj generaciji. Nakon svake naredne sječe javljaju se nove generacije izbojaka sve do n-te generacije. Poznavanje generacije izbojaka je od izuzetnog značaja za donošenje pravilne odluke kod odabira mjera njege. U slučaju da se radi o prvoj ili drugoj generaciji izbojka iz panja, za uzgojno planiranje ne treba postavljati granice, već se kod odabira postupka prevođenja u viši uzgojni oblik može računati sa dužim vremenskim periodima. Izdanačka stabla prve generacije dobro prirašćuju i razvijaju se slično stablima sjemenog porijekla. Prirast je u prvim godinama bolji a kasnije slabiji. Međutim, tehnička upotrebljivost i dimenzije bitno ne odstupaju od stabala sjemenog porijekla. U svojim istraživanjima DOHRENBUSCH (1982) je došao do rezultata koji govore da se panjače sa izbojcima prve i druge generacije u pogledu prirasta mogu porediti sa visokim šumama.

Panjača na lokalitetu „Musići“ je nastala golom sječom visoke šume bukve te izbojci unutar nje pripadaju prvoj generaciji. U prilog tome govori izgled stabala glavne etaže koja liče stablima sjemenog porijekla, dobro se razvijaju i imaju dobar visinski i debljinski prirast. Da većina stabala u panjačama bukve na teritoriji $\mathrm{BiH}$ pripada prvoj ili drugoj generaciji, ukazuje i činjenica da se u našoj zemlji ne gazduje šumama bukve niskog uzgojnog oblika.

\section{Svjetlo}

Prirodno podmlađivanje izostaje ukoliko režim svjetla unutar sastojine nije optimiran. Iako bukva važi za vrstu koja dobro podnosi zasjenu (BURSCHEL I HUSS, 1997; RöHRIG I DR., 2006), u panjačama je često, zbog veoma velikog broja izbojaka, količina svjetla nedovoljna za razvoj prirodnog podmlatka. 
U mnogim istraživanjima strukturnih karakteristika panjača, debljinska struktura stabala ima oblik opadajuće krive (MATIĆ I DR., 2003; STOJANOVIĆ I DR., 1986 a; KORIČIĆ, 2006). U nižim debljinskim klasama ima najviše stabala čiji broj opada ka višim. U pogledu vertikalne izgrađenosti javljaju se najčešće tri sprata i to: gornji, srednji i donji. Unutar panjače bukve ovakvih strukturnih karakteristika na površini tla nema dovoljno svjetla neophodnog za pojavu prirodnog podmlatka.

Istraživanja relativne jačine svjetla u panjačama bukve kod nas do sada nisu provođena. Međutim, u starim bukovim sastojinama visokog uzgojnog oblika iznad površine tla prisutno je svega 1-6 \% punog dnevnog svjetla. Pri minimalnoj relativnoj jačini svjetla, mladik bukve reaguje sa smanjenom produkcijom biomase, što pokazuju i mnogobrojna istraživanja (BURSCHEL I HUSS, 1964; SUNER I RÖHRIG, 1980; SCHMIDT, 1996). Nekolicina istraživača (upravo navedenih) smatra da kritična granična vrijednost relativne jačine svjetla za normalan razvoj podmlatka bukve iznosi od 1/5 do $1 / 10$ punog dnevnog svjetla.

Istražujući uticaj jačine svjetla na razvoj klijanaca bukve pod zastorom krošanja i na otvorenom, BURCHEL I SCHMALTZ (1965) su došli do rezultata koji ukazuju na jaku korelacionu vezu između relativne jačine svjetla i mase klijanaca, mase korijena i dužine nadzemnog dijela klijanaca. Klijanci bukve su se normalno razvijali u visinu pri jačini svjetla od $20 \%$ punog dnevnog svjetla, dok je masa korijena klijanaca koji su imali na raspolaganju $20 \%$ dnevnog svjetla bila dva puta manja u odnosu na masu onih koji su rasli na otvorenom. Biljke koje su uživale $20 \%$ dnevnog svjetla imale su 50-60\% manju apsolutnu masu suhe tvari od onih koje su rasle na otvorenom.

Stepen zastrtosti tla krošnjama stabala u panjači bukve na lokalitetu „Musići” je potpun i veći je nego u odrasloj visokoj šumi bukve, što je i osnovni razlog slabog pojavljivanja prirodnog podmlatka. Stabla iz gornje etaže su se krošnjama potpuno sklopila. U podstojnoj etaži su ostali slabiji izbojci koji su dodatno zasjenili površinu tla.

\section{Stanje tla}

Iako je strukturna izgrađenost panjača bukve u odnosu na visoku šumu bukve antropogeno narušena, za zemljište se to ne može tvrditi. Mnogobrojna istraživanja ukazuju da su zemljišta obrasla panjačama dobro očuvana (MATIĆ, 1987; PINTARIĆ, 2002). Razlaganje humusa je dobro pa nema stvaranja sirovog humusa niti dolazi do acidifikacije zemljišta. Uslijed brzog sklapanja krošanja, korovska vegetacija koja se u početku dobro razvija kasnije nestaje, slično kao i u visokim bukovim šumama. Za razliku od negativnog uticaja slabo razložene stelje, svježe opalo lišće povoljno utiče na prirodno podmlađivanje. Opalo lišće daje sjemenu zaštitu od glodara koji se njime hrane. Zaštitu sjemenkama bukve daje i umjereno gusti pokrivač prizemne vegetacije, kao što su mahovine, trave, grmovi. Nasuprot tome, gust vegetacijski pokrivač ne samo da onemogućava kontakt sjemena sa tlom, nego predstavlja jaku konkurenciju isklijalim biljkama za vodom i svjetlom. Koliko i u kojoj mjeri snabdjevenost tla mineralnim materijama i stepen kiselosti tla utiče na razvoj klijanaca nije u potpunosti razjašnjeno (GEHRMANN, 1984). 
U panjači bukve na lokalitetu „Musići” utvrđeno je dobro stanje zemljišta. Ono je očuvano sa dobrim razlaganjem stelje. Na površini tla nema sirovog humusa niti korovske vegetacije. Ovakvi uslovi tla su optimalni za otpočinjanje procesa prevođenja panjače $u$ visoku šumu postupnom oplodnom sječom. Naglim otvaranjem može doći do pojavljivanja konkurentske korovske vegetacije, a prorjeda slabog intenziteta ne bi inicirala podmlađivanje.

\section{Broj izbojaka iz panja}

Broj izbojaka iz jednog panja može biti različit i zavisi od mnogobrojnih faktora prije svega od prečnika panja (KRSTIĆ I DR., 2005). Sa povećanjem prečnika panja povećava se i broj izbojaka, njihova debljina i visina. U panjačama bukve sjeveroistočne Srbije KRSTIĆ I DR., (2005) su došli do rezultata koji govore da je prosječan broj izbojaka iz jednog panja 8,7. Za razliku od toga, na eksperimentalnim plohama „Musići I i II“ kod Sarajeva došlo se do rezultata koji ukazuju na dominaciju panjeva sa jednim do dva izbojka, dok je najmanje panjeva sa 9 -10 izbojaka (tabela $1)$.

Tabela 1. Prikaz broja panjeva sa različitim brojem izbojaka na eksperimentalnoj plohi I i II na lokalitetu „Musići“ kod Sarajeva.

Table 1. Show number of stump with different number of trees at exprimental plot I and II at the site Musici near Sarajevo

\begin{tabular}{|l|c|c|}
\hline $\begin{array}{l}\text { Broj izbojaka iz } \\
\text { panja } \\
\begin{array}{l}\text { Number of treees } \\
\text { from stump }\end{array}\end{array}$ & $\begin{array}{c}\text { Ploha I } \\
\text { Plot I }\end{array}$ & $\begin{array}{c}\text { Ploha II } \\
\text { Plot II }\end{array}$ \\
\hline \multicolumn{2}{|c|}{} & \\
\hline $1-2$ & 254 & 228 \\
\hline $3-4$ & 54 & 65 \\
\hline $5-6$ & 11 & 13 \\
\hline $7-8$ & 2 & 5 \\
\hline $9-10$ & 2 & - \\
\hline
\end{tabular}

Manji broj izbojaka iz panja pogoduje boljem razvoju stabla u pogledu količine proizvedenog drveta i kvaliteta. Panjače sa manje izbojaka iz panja imaju strukturu koja odgovara jednodobnim jednoslojnim sastojinama, dok one sa više izbojaka iz jednog panja imaju ,prebornu strukturu“. Ovakva debljinska struktura stabala predstavlja dodatni problem kod poduzimanja mjera njege i prevođenja u viši uzgojni oblik. Sa starošću izdanačkih šuma dolazi do prirodnog izlučivanja i uslijed konkurencije do postepenog odumiranja pojedinih izbojaka. Međutim, ovaj proces je dosta usporen ako se ima u vidu da bukva dobro podnosi zasjenu, tako da potišteni izbojci uživajući difuzno svjetlo dugo zadržavaju vitalnost oduzimajući vodu i mineralne materije odabranim izbojcima sa panja. 


\section{Stara stabla- ̌̌ubarci}

U Bosni i Hercegovini postoji jedan oblik degradiranih panjača sa većim ili manjim brojem šubaraka - stabala sjemenog porijekla, koja su dugo vremena služila za sječu lisnika (MEKIĆ, 1998). Šubarci su stara stabla jako velikog prečnika i nepravilnog kvrgavog debla sa nisko nasađenom i dobro razvijenom krošnjom. Stabla iz kojih su nastali šubarci su korištena za dobivanje lisnika. Ovakva stabla se obično nalaze pored sela u nižem brdskom pojasu bukve i čine poseban vid degradirane šume. Ona su sporadično prisutna i u panjačama bukve.

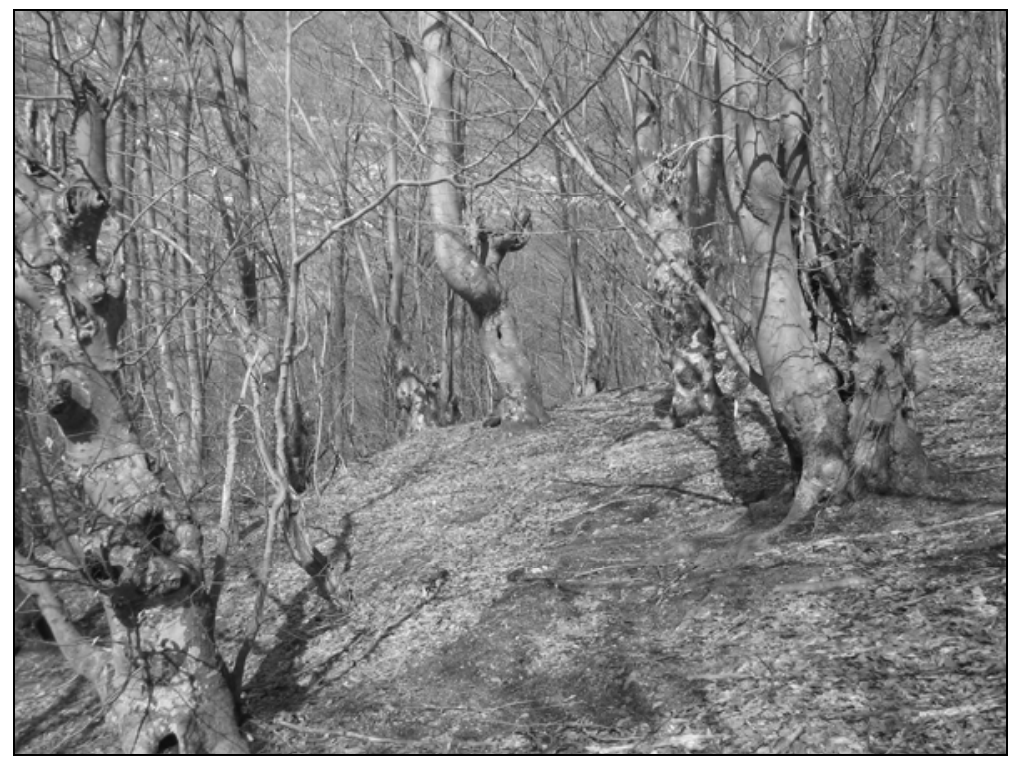

Slika 3. Degradirana panjača sa velikim udjelom šubaraka (foto Višnjić Ć.)

Foto 3. Degraded beech coppice forest with big part of huge bed trees

Sječom šubaraka stvaraju se veće progale. Na progalama se intezivno razvija korovska vegetacija koja onemogućava prirodno podmlađivanje. Redukcija krošnje šubaraka je zahtjevan posao i njom se ne ostvaruje dobar efekat zbog brzog popunjavanja krošnje novim granama. Tlo unutar ovih šuma je očuvano, ali je jako zasjenjeno. Stelja se dobro razlaže i nema stvaranja sirovog humusa. Nema korovske vegetacije niti prirodnog podmlatka. Panjače sa velikim udjelom šubaraka u podstojnoj etaži imaju uslove slične onim u visokim bukovim šumama. Ovo upućuje na pravce djelovanja u cilju prevođenja ovih šuma $u$ visoke oplodnom sječom uz optimiranje svjetla tokom obnove (BURCSCHEL I HUSS, 1997; RÖHRIG I DR., 2006). 


\section{Stabla sjemenog porijekla}

U dosadašnjim istraživanjima strukturnog sastava panjača bukve, pored stabala vegetativnog evidentiran je i određeni broj stabala sjemenog porijekla (STOJANOVIĆ I DR., 1983; KRSTIĆ I DR., 2005); PINTARIĆ, (2002) je na eksperimentalnim plohama u panjačama bukve utvrdio izvjestan broj stabala sjemenog porijekla koji se kretao od 52 do 286 po ha ili od $4 \%$ do $32 \%$ ukupnog broja stabala. Osim bukve na plohama su bile zastupljene i druge vrste drveća sjemenog porijekla (javor, jasen, brijest, lipa). Ove vrste se uglavnom nalaze u istim debljinskim stepenima kao i bukva (od 5 do $30 \mathrm{~cm}$ ), tako da postoje realni uslovi da se primjenom mjera njege ove panjače prevedu u visoku mješovitu šumu lišćara (PINTARIĆ, 2002). Veći broj stabala sjemenog porijekla pravilno raspoređenih po površini upućuju na uzgojne zahvate koji imaju za cilj pomaganje tih stabala, do vremena kada sastojina dosegne punu zrelost kada bi se provela oplodna sječa sa podmladnim razdobljem od 10-15 godina. Ako je broj stabala sjemenog porijekla u panjači manji, onda kod odabira metoda prevođenja u viši uzgojni oblik treba imati na umu druge kriterije (kvalitet izdanačkih stabala, njihov broj i raspored i dr.), a sjemenska stabla treba zadržati. Nekada je teško napraviti razliku između izdanačkog i stabla sjemenog porijekla, posebno u odraslim izdanačkim šumama u kojima se iz panja javlja jedno stablo. Osnovna razlika je što izdanačka stabla imaju sabljast izgled u pridanku, dok su sjemenska stabla prava sa korijenom pravilno razvijenim sa svih strana. Međutim, nekada je i na taj način teško razlučiti da li je stablo sjemenskog ili vegetativnog porijekla, pa se tek analizom stabla može utvrditi razlika. Stabla vegetativnog porijekla u početku imaju bolji prirast od stabala sjemenog porijekla. Na presjeku stabla to se vidi na godovima, koji su kod izdanačkih stabala u centralnom dijelu širi. Stabla sjemenog porijekla imaju bolje i pravilnije deblo i zdravija su od stabala vegetativnog porijekla. Starija stabla vegetativnog porijekla najčešće imaju centralnu trulež koja se širi iz starog panja pa je i kvalitet drveta za tehničku upotrebu znatno lošiji. Na lokalitetu "Musići" preko $95 \%$ stabala su vegetativnog porijekla i ona u potpunosti dominiraju u panjači. Samo mali broj je sjemenog porijekla i uglavnom se radi o drugim pionirskim vrstama drveća.

\section{Prirodni podmladak}

Prirodnom podmlatku u panjačama bukve se do sada posvećivalo malo pažnje. U prilog ovome govori činjenica da se dugoročnim planovima razvoja šumarstva u $\mathrm{BiH}$ predviđalo prevođenje izdanačkih šuma bukve u visoko vrijedne kulture četinara, te se nije vodilo računa o stanju i kvalitetu prirodnog podmlatka (MATIĆ I DR., 1971); STOJANOVIĆ I DR., (1986), u svojim istraživanjima govore da se ponik i podmladak bukve i ostalih vrsta drveća u panjačama bukve javlja rijetko. Oni dalje naglašavaju da zbog toga podaci o podmlatku nemaju praktičnog značaja prilikom odlučivanja da li treba primijeniti direktnu ili indirektnu konverziju panjača bukve u sastojine višeg uzgojnog oblika.

Međutim, prirodni podmladak ima izuzetan značaj za budući razvoj i prevođenje panjača bukve u viši uzgojni oblik. Pojavljivanje jele u prirodnom 
podmlatku neosporno ukazuje na činjenicu da su neke panjače nastale iz visokih sekundarnih šuma bukve koje su primarno predstavljale zajednice bukve i jele. Do sličnih zaključaka o vertikalnom zoniranju primarne šumske vegetacije došao je i BEUS (1984). U takvim panjačama, koje u BiH zauzimaju značajne površine, trebalo bi stvoriti uslove za obnavljanje jele, naletom sjemena sa strane ili podsijavanjem. Na eksperimentalnim plohama na lokalitetu "Musići”" prirodni podmladak je skoro u potpunosti izostao. Iako panjača urađa, podmlatka bukve nema. Ovo se može objasniti sklopom panjače, koji je potpun, a zbog nedostatka svjetla izostaje i podmlađivanje.

\section{Strukturne karakteristike}

U tabeli 2 i dati su osnovni taksacioni pokazatelji panjače bukve na eksperimentalnoj plohi I "Musići" kod Sarajeva. Svi podaci mjereni na plohi preračunati su na hektar.

Tabela 2. Struktura 60 - godišnje panjače bukve po broju stabala iz sjemena i panja, vrstama drveća debljinskim stepenima na oglednoj plohi I "Musići" kod Sarajeva

Table 2. The structure of 60-jear old beech coppice by the number of trees from seeds and stumps, tree species and diametar degrees at experimental plot I "Musići" near Sarajevo

\begin{tabular}{|c|c|c|c|c|c|c|c|c|c|c|}
\hline \multirow[t]{3}{*}{$\mathrm{d}$} & \multicolumn{3}{|c|}{ Bukva-Beech } & \multicolumn{2}{|c|}{$\begin{array}{c}\text { Grab - } \\
\text { Hornbeam }\end{array}$} & \multicolumn{2}{|c|}{$\begin{array}{c}\text { Ostale vrste } \\
\text { Others species }\end{array}$} & \multicolumn{2}{|c|}{$\begin{array}{c}\text { Ukupno } \\
\text { Total }\end{array}$} & \multirow{3}{*}{\begin{tabular}{|c|}
$\begin{array}{c}\text { Ukupno } \\
\text { Total }\end{array}$ \\
Sjeme + Panj \\
Seed + Stump
\end{tabular}} \\
\hline & \multicolumn{2}{|c|}{ Sjeme } & \multirow{2}{*}{$\begin{array}{l}\text { Panj } \\
\text { Stump }\end{array}$} & \multirow{2}{*}{$\begin{array}{l}\text { Sjeme } \\
\text { Seed }\end{array}$} & \multirow{2}{*}{\begin{tabular}{|l|} 
Panj \\
Stump
\end{tabular}} & \multirow{2}{*}{$\begin{array}{l}\text { Sjeme } \\
\text { Seed }\end{array}$} & \multirow{2}{*}{$\begin{array}{l}\text { Panj } \\
\text { Stump }\end{array}$} & \multirow{2}{*}{\begin{tabular}{|l|} 
Sjeme \\
Seed
\end{tabular}} & \multirow{2}{*}{$\begin{array}{l}\text { Panj } \\
\text { Stump }\end{array}$} & \\
\hline & \begin{tabular}{|l|} 
Stablo \\
treee
\end{tabular} & Šubarak & & & & & & & & \\
\hline $\mathrm{cm}$ & \multicolumn{10}{|c|}{ kom./ha-pcs/ha } \\
\hline $5-10$ & & & 1220 & 24 & 12 & 8 & & 32 & 1232 & 1264 \\
\hline $10-15$ & 8 & & 732 & & 12 & 12 & & 20 & 744 & 764 \\
\hline $15-20$ & 4 & & 352 & & 8 & 4 & & 8 & 360 & 368 \\
\hline $20-30$ & & & 188 & & & & & & 188 & 188 \\
\hline $30-50$ & & & 4 & & & & & & 4 & 4 \\
\hline $50-80$ & & 4 & & & & & & 4 & & 4 \\
\hline$>80$ & & 8 & & & & & & 8 & & 8 \\
\hline $\begin{array}{l}\text { Ukupno } \\
\text { Total }\end{array}$ & 12 & 12 & 2496 & 24 & 32 & 24 & & 72 & 2528 & 2600 \\
\hline
\end{tabular}

Na prvoj eksperimentalnoj plohi, na kojoj je provedena selektivna prorjeda, evidentirano je 2600 stabala po ha. Dominira bukva vegetativnog porijekla sa oko 96 $\%$. Pored bukve zastupljen je grab vegetativnog porijekla, te hrast kitnjak i jarebika sjemenog porijekla. Evidentirano je i 12 šubaraka različitih dimenzija. Raspored stabala po debljinskim stepenima ima izgled opadajuće krive, slično kao u prebornoj sastojini. Najveći broj stabala zastupljen je u najnižem debljinskom stepenu i opada prema većim. Ako se samo analiziraju stabla sjemenog porijekla, uočava se da su i ona najviše zastupljena u najnižem a njihov broj se smanjuje prema većim debljinskim stepenima. 
Tabela 3. Struktura 60 - godišnje panjače bukve po broju stabala iz sjemena i panja, vrstama drveća i debljinskim stepenima na oglednoj plohi II "Musići" kod Sarajeva

Table 3. The structure of 60-jear old beech coppice by the number of trees from seeds and stumps, tree species and diametar degrees at experimental plot II "Musici" near Sarajevo

\begin{tabular}{|c|c|c|c|c|c|c|c|c|c|c|}
\hline \multirow{3}{*}{$\mathrm{d}$} & \multicolumn{3}{|c|}{ Bukva-Beech } & \multicolumn{2}{|c|}{$\begin{array}{c}\text { Grab - } \\
\text { Hornbeam }\end{array}$} & \multicolumn{2}{|c|}{$\begin{array}{l}\text { Ostale vrste } \\
\text { Other species }\end{array}$} & \multicolumn{2}{|c|}{$\begin{array}{c}\text { Ukupno } \\
\text { Total }\end{array}$} & \multirow{3}{*}{\begin{tabular}{|c|}
$\begin{array}{c}\text { Ukupno } \\
\text { Total }\end{array}$ \\
$\begin{array}{l}\text { Sjeme + Panj } \\
\text { Seed + Stump }\end{array}$
\end{tabular}} \\
\hline & \multicolumn{2}{|c|}{ Sjeme } & \multirow{2}{*}{$\begin{array}{l}\text { Panj } \\
\text { Stump }\end{array}$} & \multirow{2}{*}{$\begin{array}{l}\text { Sjeme } \\
\text { Seed }\end{array}$} & \multirow{2}{*}{$\begin{array}{l}\text { Panj } \\
\text { Stump }\end{array}$} & \multirow{2}{*}{$\begin{array}{l}\text { Sjeme } \\
\text { Seed }\end{array}$} & \multirow{2}{*}{$\begin{array}{l}\text { Panj } \\
\text { Stump }\end{array}$} & \multirow{2}{*}{$\begin{array}{l}\text { Sjeme } \\
\text { Seed }\end{array}$} & \multirow{2}{*}{$\begin{array}{l}\text { Panj } \\
\text { Stump }\end{array}$} & \\
\hline & \begin{tabular}{|l|}
$\begin{array}{l}\text { Stablo } \\
\text { treee }\end{array}$ \\
\end{tabular} & Šubarak & & & & & & & & \\
\hline $\mathrm{cm}$ & \multicolumn{10}{|c|}{ kom./ha $-p c s / h a$} \\
\hline $5-10$ & 8 & & 756 & 44 & 292 & 8 & & 60 & 1044 & 1104 \\
\hline $10-15$ & 4 & & 532 & 24 & 136 & 4 & & 32 & 668 & 700 \\
\hline $15-20$ & 8 & & 484 & 8 & 20 & 8 & & 24 & 504 & 528 \\
\hline $20-30$ & 4 & & 236 & & & 4 & & 8 & 236 & 244 \\
\hline $30-50$ & & 4 & & & & & & 4 & 0 & 4 \\
\hline $50-80$ & & 4 & & & & & & 4 & 0 & 4 \\
\hline$>80$ & & & & & & & & & & \\
\hline \begin{tabular}{|l} 
Ukupno \\
Total
\end{tabular} & 24 & 8 & 2008 & 76 & 448 & 24 & & 132 & 2452 & 2588 \\
\hline
\end{tabular}

Slični pokazatelji su i na eksperimentalnoj plohi II (tabela 3). Od ukupno 2588 stabala po hektaru dominira bukva vegetativnog porijekla sa oko $80 \%$, dok bukve sjemenog porijekla ima svega $1 \%$. U panjači je u znatnoj mjeri zastupljen i grab sa oko $19 \%$, koji je također vegetativnog porijekla. Od ostalih vrsta u panjači su u malom broju prisutni hrast kitnjak, jarebika i breza. Sve vrste su sjemenog porijekla. Pored toga, u panjači je evidentirano i nekoliko šubaraka koji su u predominantnoj etaži i predstavljaju smetnju za razvoj stabala dominantne i subdominantne etaže. Najveći broj stabala zastupljen je u najnižem i opada prema većim debljinskim stepenima.

Zapremina panjače na prvoj eksperimentalnoj plohi iznosi $331,7 \mathrm{~m}^{3} / \mathrm{ha}$. Doznakom stabala uklonjeno je $67 \mathrm{~m}^{3} /$ ha, tako da intenzitet prorjede po zapremini sastojine iznosi $20,2 \%$. Intenzitet prorjede po broju stabala je znatno manji i iznosi $11,5 \%$. Ovo govori da je prorjedom uklonjen manji broj debljih stabla koji su direktni konkurenti odabranim stablima, čijom su sječom stvoreni povoljniji uslovi unutar sastojine za razvoj odabranih stabala. Intenzitet prorjede po temeljnici iznosi $27 \%$, što je dovoljno za pojavljivanje prirodnog podmlatka. 
Tabela 4. Taksacioni pokazatelji na eksperimentalnim plohama prije i nakon provedenih prorjeda u panjači bukve na lokalitetu "Musići" kod Sarajeva.

Table 4. Inventory elements at experimental plots before and after thinning in beech coppice forest at the site "Music"i near Sarajevo

\begin{tabular}{|c|c|c|c|c|c|c|c|c|c|c|c|c|c|c|}
\hline \multicolumn{6}{|c|}{$\begin{array}{l}\text { Stanje prije prorjede } \\
\text { Stand before thinning }\end{array}$} & \multicolumn{6}{|c|}{$\begin{array}{l}\text { Prorjedni materijal } \\
\text { Thinning material }\end{array}$} & \multicolumn{3}{|c|}{$\begin{array}{l}\text { Intenzitet } \\
\text { Intesity }\end{array}$} \\
\hline \multicolumn{14}{|c|}{ Ploha I(selektivna prorjeda) } & Plot I (selective thinning) \\
\hline $\mathrm{N}$ & $\mathrm{N}(\mathrm{ha})$ & $\mathrm{G}\left(\mathrm{m}^{2}\right)$ & G(ha) & $\mathrm{V}\left(\mathrm{m}^{3}\right)$ & $\mathrm{V}(\mathrm{ha})$ & $\mathrm{N}$ & $\mathrm{N}(\mathrm{ha})$ & $\mathrm{G}\left(\mathrm{m}^{2}\right)$ & $\mathrm{G}(\mathrm{ha})$ & $\mathrm{V}\left(\mathrm{m}^{3}\right)$ & $\mathrm{V}(\mathrm{ha})$ & N\% & G\% & $\mathrm{V} \%$ \\
\hline 650 & 2600 & 9,25 & 37,0 & 82,9 & 332 & 75 & 300 & 2,49 & 9,9 & 16,7 & 67,0 & 11,5 & 26,9 & 20,2 \\
\hline \multicolumn{15}{|c|}{$\begin{array}{c}\text { Ploha II (selektivna prorjeda uz uklanjanje loših izbojaka na panju) } \\
\text { Plot II ( selective thinning wth cating of bed stams) }\end{array}$} \\
\hline $\mathrm{N}$ & N(ha) & $\mathrm{G}\left(\mathrm{m}^{2}\right)$ & G(ha) & $\mathrm{V}\left(\mathrm{m}^{3}\right)$ & V(ha) & $\mathrm{N}$ & $\mathrm{N}$ (ha) & $\mathrm{G}\left(\mathrm{m}^{2}\right)$ & $\mathrm{G}$ (ha) & $\mathrm{V}\left(\mathrm{m}^{3}\right)$ & $\mathrm{V}$ (ha) & N\% & G\% & $\mathrm{V} \%$ \\
\hline 647 & 2588 & 9,5 & 37,8 & 90,3 & 361 & 212 & 848 & 2,8 & 11,3 & 25,3 & 101 & 32,8 & 29,8 & 28,0 \\
\hline
\end{tabular}

$\mathrm{Na}$ drugoj eksperimentalnoj plohi, gdje je provedeno odabiranje stabala uz reduciranje zaostalih i loših izbojaka sa panja, provedena je prorjeda jačeg intenziteta i po zapremini i po broju stabala. Iz tabele 1 se vidi da je intenzitet prorjede po broju stabala veći od intenziteta po zapremini. To nam govori da je prorjedom zahvaćen veći broj stabala iz donje etaže. Prorjedom je uklonjeno oko $30 \%$ temeljnice, što je dovoljno za otpočinjanje prirodnog podmlađivanja (BURSCHEL I HuSS, 1997).

Na grafikonu 1 dat je prikaz stanja u panjači bukve na lokalitetu "Musići” na eksperimentalnim plohama I i II prije i nakon provedenih prorjeda. $\mathrm{Na}$ eksperimentalnoj plohi I provedena je klasična Schaedelinova prorjeda, dok je na eksperimentalnoj plohi II provedena Schaedelinova prorjeda uz uklanjanje zaostalih i loših izbojaka sa panja.

\begin{tabular}{|l|l|l|}
\hline $\begin{array}{l}\text { Ploha 1: stanje prije sječe- stand before } \\
\text { thinning }\end{array}$ & $\begin{array}{l}\text { Ploha 2: stanje prije sječe- stand before } \\
\text { thinning }\end{array}$ \\
\hline
\end{tabular}




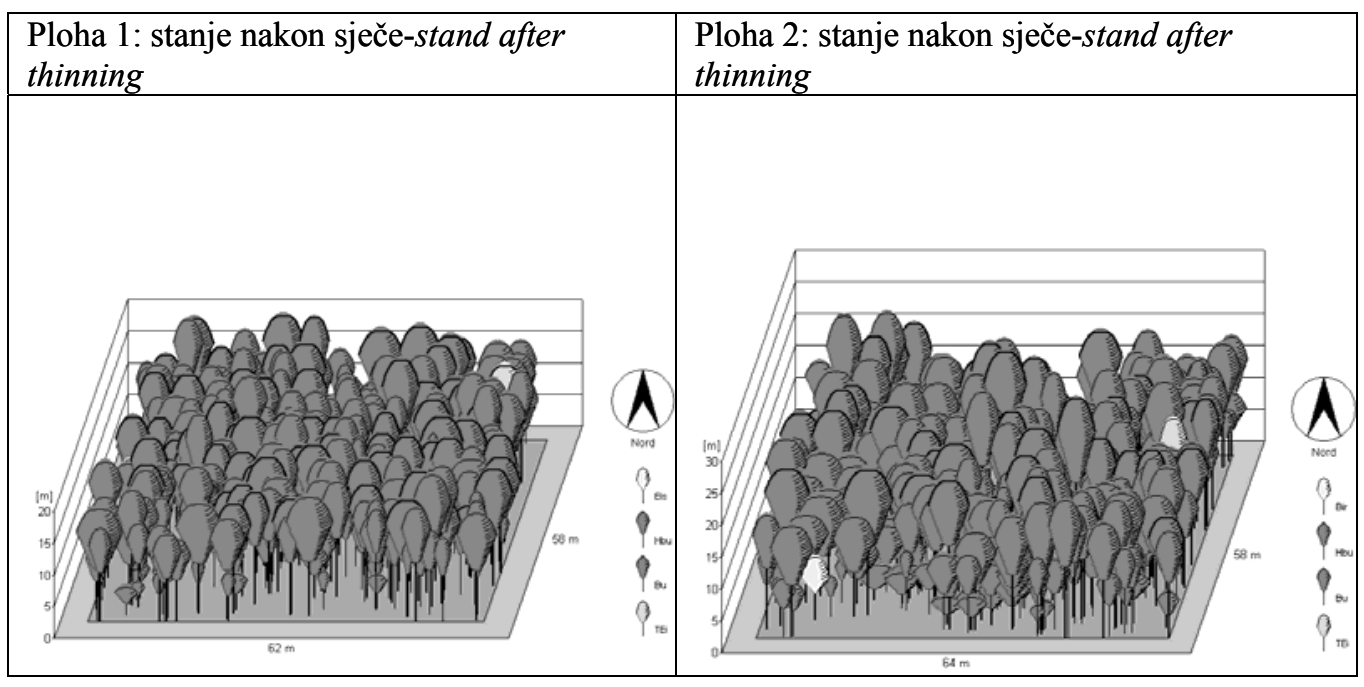

Grafikon 1. Stanje prije i nakon provedene prorjede na eksperimentalnim plohama I i II Graf 1. Condition before and after thinning at experimental plots I and II

Bu- bukva- beech, TEi- hrast kitnjak- sessile oak, Br - breza- silver birch, Hbu-grabhornbeam, Eis- Sorbus sp

odabrana stabla - selected trees
doznačena - trees for cating

Na plohi I, gdje je provedena selektivna prorjeda odabrana su 332 stabla po hektaru. Odabrana stabla su pravilno raspoređena sa podjednakim razmakom. Najveći dio odabranih stabala pripada predominantnoj i dominantnoj etaži po Krafu. Stabla su odabrana po principima Schädelinove selektivne prorjede a doznačena su samo ona koja smetaju odabranim (grafikon 1). Broj doznačenih stabala je mali i iznosi 300 po hektaru. Međutim, doznačena stabla su uglavnom glavni konkurenti i pripadaju gornjoj i srednjoj etaži, pa i doznačena masa iznosi $67 \mathrm{~m}^{3} /$ ha što je $20 \%$ od ukupne zapremine sastojine. Na eksperimentalnoj plohi II odabrano je 188 stabala koja su pravilno raspoređena po površini (grafikon 1). Odstranjeni su najveći konkurenti odabranim stablima kao i sva ostala zaostala i loša stabla sa panja iz 4-te i 5-te klase po Kraftu. Ukupno je doznačeno 848 stabala ili $32,8 \%$. Pored ovako velikog broja doznačenih stabala, za razliku od onog na plohi I, udio doznačene zalihe (28 \%) nije bio značajno veći od one sa plohe I (20\%). Ovo govori da i pored značajno većeg intenziteta prorjede po broju stabala na plohi II, intenzitet po zapremini nije bio proporcionalno veći.

Iz grafikona 1 se vidi da je i pored različitog načina doznačivanja na eksperimentalnim plohama I i II, sklop panjače ostao sačuvan na obje plohe, što je svakako značajno sa aspekta očuvanja stabilnosti sastojine. Iako je na eksperimentalnoj plohi II odabran manji broj stabala, njihov raspored po čitavoj površini je dobar (grafik 1). Uklanjanjem zaostalih i loših stabala sa panja oslobađaju se odabrana stabla od konkurencije za vodom i mineralnim materijama a unutar 
sastojine se dovodi više svjetla, što je primarni uslov za pojavljivanje prirodnog podmlatka.

\section{Diskusija - Discussion}

Prema ALIKALFIĆU (1970), i KRSTIĆU (2002) sposobnost vegetativnog razmnožavanja je složen pojam koji je raščlanjen na: izdanačku sposobnost pojedinih vrsta drveća - izdanačku energiju koja je izražena dužinom izbojka u toku jednog vegetacionog perioda, izdanačku bazu - koja je izražena dimenzijama panjeva iz kojih se formiraju izbojci i generaciju izbojka- sposobnost biljke da nakon sječe starih ponovo razvije izbojke. Prema mnogim istraživačima bukva spada u vrste drveća sa slabom izbojnom sposobnošću, sa dužinom izbojaka u prvoj godini od 50 do $80 \mathrm{~cm}$ (PotT, 1985; Ellenderg, 1996; Burschel I Huss, 1997; SCherzinger, 1996). Stoga korištenje drveta bukve u kraćim turnusima a na bazi regeneracione sposobnosti, nije ekonomski opravdano. Ovo potvrđuje činjenicu da panjače bukve kod nas nisu nastale gazdovanjem šumama bukve niskim uzgojnim oblikom, već stihijskim i nekontrolisanim sječama uglavnom za potrebe ogrjeva (PINTARIĆ, 2002; MATIĆ I DR., 2003). Zbog toga pojam "niske šume bukve" u Bosni nije vezan za način gospodarenja nego za vegetativno porijeklo stabla.

Još 50-ih godina prošlog stoljeća istraživane su mogućnosti poboljšanja kvaliteta panjača (PATAKY, 1956; KOLAKOVIĆ, 1960; ĐIKIĆ, 1960), pri čemu su analizirane i prirasne mogućnosti ovih šuma (ĐIKIĆ I KOLAKOVIĆ, 1965; VUKMIROVIĆ I StOJANOVIĆ, 1966; AliKALFIĆ, 1970). Predloženo je prevođenje panjača u visoke direktnom $\mathrm{i}$ indirektnom konverzijom, što u praksi nije u potpunosti primijenjeno. $\mathrm{U}$ Bosni i Hercegovini su se obimnija istraživanja oko panjača bukve provodila sredinom 80-ih godina prošlog vijeka (STOJANOVIĆ I DR., 1986 a). Rezultati ovih istraživanja daju smjernice koje govore da panjače sa udjelom kvalitetnih stabala od najmanje 200 po hektaru treba prevoditi u viši uzgojni oblik indirektnom konverzijom, dok one lošeg kvaliteta treba prevoditi direktnom konverzijom u visoke.

Direktna konverzija sa izmjenom vrsta je dosta zahtjevna i iziskuje veće troškove u poređenju sa indirektnom konverzijom (DOHRENBUSCH, 2002). Pored toga nesiguran je uspjeh pošumljavanja na golim površinama bez zaštite krošanja odraslih stabala ako se ima u vidu činjenica da se mikroklima nakon provedenih golih sječa znatno mijenja (GEIGER, 1961). Pokušaji pošumljavanja golih površina u centralnoj Bosni, koje su nastale stihijskim sječama panjača, bili su dosta neuspješni (VIŠNJIĆ, 2006). U istraživanju podmlađivanja bukve u jugoistočnoj Evropi GARELKOV (1979) govori da se prirodni podmladak u visokim šumama bukve koje rastu na južnim i jugo-zapadnim ekspozicijama te na nagnutim terenima teško razvija i stalno je u stresu zbog nedostatka vode. BURLICA I STEFANOVIĆ (1988) su ukazali na ekološke rizike koji mogu nastati uslijed golih sječa u panjačama u Bosni i Hercegovini zbog direktne konverzije u visoke šume. DOHRENBUSCH (2002) preporučuje da se u panjačama na jako nagnutim i terenima koji su ugroženi od erozije ne provodi direktna konverzija, nego da se prevođenje u visoke šume vrši indirektno, koristeći mogućnosti prirodnog podmlađivanja. Ovo je za panjače bukve u Bosni i Hercegovini od izuzetnog značaja 
ako se imaju u vidu njihove stanišne prilike. Po HoELSCHERU I DR. (2001), struktura tla unutar panjača je narušena, tlo raspolaže sa znatno manjom zalihom humusa i mineralnih materija $u$ odnosu na tlo u visokim bukovim šumama. Zbog toga je nakon gole sječe panjače sposobnost regeneracije vegetacije izuzetno otežana. Ova teza se može prihvatiti za panjače u kojim se gospodari niskim uzgojnim oblikom. Panjače bukve u $\mathrm{BiH}$, prema mnogim istraživačima, imaju strukturno dobro očuvana tla (STOJANOVIĆ I DR., 1986; PINTARIĆ, 2002; MATIĆ I DR., 2003).

Upitna je i direktna konverzija sa izmjenom vrsta, npr. pošumljavanjem bijelim borom ili smrčom. Bijeli bor i smrča pokazuju veće prinosne mogućnosti i zbog toga se čine ekonomski interesantnije od bukve. Međutim, bijeli bor kao vrsta svjetla pospješuje revitalizaciju prizemne vegetacije koja izuzetno otežava obnavljanje u sljedećim generacijama (BOLTE, 1999 a), a prizemna vegetacija je u sušnom periodu jak konkurent stablima bora u pogledu snabdijevanja vodom (MUELLER I DR., 1998; BOLTE I DR., 2001; MUELLER I BOLTE, 2002). Pored toga bijeli bor je jako ugrožen od snjegoloma, a smrča od vjetroizvala (PETRI, 1976; LESSEL-DUMmEL, 1979). U BiH su kulture bijelog bora koje su zasađene na staništima bukve i hrasta izuzetno ugrožene od snjegoloma, posebno u brdskim i brdsko-planinskim područjima. Na kraju, ako je opredjeljenje direktna konverzijasa unošenjem četinara prije pošumljavanja treba napraviti studiju o mogućnostima prodaje, korištenja i asortimana proizvoda drveta četinara na tržištu. Uopćeno poznato je da je bolje imati širu paletu proizvoda kako bi se izbjegli problemi sa opadanjem potražnje za jednim i moglo se adekvatno reagovati ponudom sa drugim proizvodom. Zbog toga je koncentracija aktivnosti šumara na proizvodnji četinara sa ekonomskog aspekta neprihvatljiva.

Alternativa direktnoj je indirektna konverzija panjača bukve u visoke. To ima smisla samo onda kada unutar panjače ima dovoljan broj kvalitetnih stabala koja su pravilno raspoređena po čitavoj površini (STOJANOVIĆ I DR., 1986 a, PINATRIĆ, 2002). Broj izbojaka na panju se u početku reducira. Na kraju se panjačom gazduje kao i visokom šumom. U poređenju sa direktnom konverzijom, prednosti ovog postupka se ogledaju u manjem intenzitetu sječa, korištenju boljeg početnog prirasta panjače i minimiziranju ekoloških rizika.

Kako je rečeno, broj izbojaka iz jednog panja je različit. Kako i na koji način provesti mjere njege i obnove u velikoj mjeri zavisi od broja izbojaka iz jednog panja. Optimalno bi bilo da iz jednog panja ima jedan ili dva izbojka. Panjače bukve sa jednim izbojkom u starosti od 60 do 70 godina slične su visokim bukovim šumama. Uzgojne mjere i obnavljanje ovih šuma u potpunosti mogu odgovarati visokim. Kvalitet drveta je lošiji u visokim ali drvo ima tehničku vrijednost (KoRIČıć, 2006). U panjačama sa više izbojaka iz panja potrebno je istovremeno sa odabiranjem stabala izvršiti i čišćenje u donjoj etaži. Taj način prorjeđivanja ne odgovara u potpunosti nizi selektivnoj niti regularnoj prorjedi po MATIĆU (1987). U ovakvim panjačama može se govoriti o njezi i odabiranju slično kao u prebornim šumama gdje se istovremeno odabire, njeguje i provode mjere zakašnjelog čišćenja. Sličan način prorjeđivanja izvršen je na oglednoj plohi II na lokalitetu Musići. Ovim zahvatom je istovremeno izvršeno i čišćenje i selekcija odnosno pomaganje najboljim stablima. Nakon prorjede, struktura sastojine se pomjerila od „preborne“ prema strukturi jednodobne sastojine. 
Naredna prorjeda bi imala karakter klasične selektivne prorjede uz pomaganje najboljih stabala i uklanjanje njihovih konkurenata.

Istraživanja svjetlosti kao ekološke komponente unutar panjača do sada su bila fokusirana uglavnom na optimiranje intenziteta svjetla za rast i razvoj izbojaka a ne na pospješivanje prirodnog podmlađivanja (JOHANNSON, 1986, 1987, 1991; YOSHIDA I KAMITANI, 1996; GARDINER I HeLmIG, 1997; RYDBERG, 2000). Zbog toga je potrebno u daljim istraživanjima najveću pažnju posvetiti prirodnom podmlađivanju i optimiranju intenziteta svjetla u funkciji prirodnog podmlađivanja panjača bukve.

Analizirajući sve dosadašnje metode za prevođenjenje izdanačkih šuma bukve u visoke, uviđa se veliki broj različitih rješenja koja su manje-više složena. Postupke prevođenja je potrebno pojednostaviti. Unutar panjače prednost treba dati najboljim izdanačkim stablima bukve, kao i onim koja u toku provođenja uzgojnih mjera imaju druge značajne funkcije za očuvanje stabilnosti šume. Pored njih, pažnju treba posvetiti i stablima drugih vrsta koja su od izuzetnog značaja za očuvanje i unapređenje stanja biodiverziteta. Odabrana stabla se u ovom slučaju ne mogu porediti sa onim u visokoj šumi, niti je krajnji cilj prorjede u panjačama isti kao i u visokim.

\section{Zaključak - Conclusion}

Panjače bukve u BiH zauzimaju površinu od 351.000 ha i nalaze se uglavnom na dobrim staništima čiji proizvodni potencijal nije u potpunosti iskorišten. Zbog toga se u drugoj polovici prošlog stoljeća prišlo intenzivnom prevođenju ovih šuma u viši uzgojni oblik. Svi metodi i postupci prevođenja zasnivali su se na direktnoj i indirektnoj konverziji. Navedena istraživanja ukazuju da direktnu konverziju treba izbjegavati zbog negativnih posljedica koje mogu da nastanu uslijed izmjene stanišnih uslova ili lošeg izbora vrste drveća koja se sadi nakon sječe panjače. Indirektna konverzija uz optimiranje uzgojnih mjera može dati dobre rezultate. Za panjače mlađe od 60 godina preporučuju se selektivne prorjede uz ostavljanje 200-300 odabranih stabala po hektaru koja su pravilno raspoređena po površini. Za starije panjače predlaže se oplodna sječa u cilju podmlađivanja.

Radi objektivnije odluke izbora mjera njege potrebno je poznavati sastojinske prilike panjače u kojoj će se vršiti zahvat. Od stanišnih i strukturnih pokazatelja najvažniji su: starost panjače, generacija izbojka, broj izbojaka iz panja, stanje tla, broj stabala sjemenog porijekla, prisustvo šubaraka, prisustvo prirodnog podmlatka, struktura sastojine po broju stabala i prečniku. Pored njih, potrebno je poznavati stepen zastrtosti tla krošnjama stabala i intenzitet svjetla unutar panjače. Svjetlo kao ekološki faktor je od izuzetnog značaja za mikrobiološku aktivnost u tlu, razlaganje humusa i prije svega za pojavljivanje prirodnog podmlatka.

Panjača na lokalitetu "Musići", na osnovu analize navedenih faktora, ima optimalne uslove za otpočinjanje postupka indirektne konverzije u viši uzgojni oblik selektivnom prorjedom uz početno uklanjanje zaostalih i loših izbojaka sa panja.

Panjača na lokalitetu Musići je nastala sječom visoke šume te izbojci pripadaju prvoj generaciji. Zbog toga sa njima u budućnosti treba postupati kao sa stablima u visokoj 
šumi. Najveći broj stabala je u nižim debljinskim klasama i smanjuje se prema višim, pa je struktura izdanačke šume po prečniku slična "prebornoj“.

U panjači su evidentirani i šubarci, koji su jako razvijeni te prave konkurenciju ostalim kvalitetnim izbojcima i onemogućavaju prirodno podmlađivanje. Tlo je potpuno sačuvano. Razgradnja stelje je dobra i nema nakupljanja sirovog humusa. Stabala sjemenog porijekla ima veoma malo i pripadaju drugim vrstama drveća. Prirodni podmladak je pojedinačno zastupljen.

U panjači ima najviše panjeva iz kojih se razvija jedan do dva izbojka. Maksimalni broj izbojaka iz jednog panja je 10 i takvih panjeva je svega dva po hektaru.

$\mathrm{Na}$ dvije eksperimentalne plohe su provedena dva načina prorjeđivanja i to: selektivna prorjeda i selektivna prorjeda uz uklanjanje zaostalih i loših izbojaka sa panja. Intenzitet selektivne prorjede po broju stabala iznosio je $11,5 \%$ i bio je znatno manji od intenziteta selektivne prorjede sa uklanjanjem zaostalih i loših stabala sa panja (32,8 \%). Intenzitet po temeljenici je bio približno isti (selektivna prorjeda 26,9 $\%$, selektivna prorjeda uz uklanjanje zaostalih stabala 29,8 \%).

$\mathrm{Na}$ osnovu navedenog može se zaključiti da je tokom provođenja prorjede $u$ panjači poželjno, pored uklanjanja direktnih konkurenata, reducirati i broj stabala sa panja uklanjajući loša i stabla zaostala u rastu. Na taj način efekti prorjeđivanja su bolji, naročito ako se ima u vidu da se čišćenjem loših i zaostalih izbojaka sa panja, i to umanjuje konkurencija odabranim stablima u pogledu vode i mineralnih materija. Pored toga, na površini tla dolazi više svjetla koje pospješuje mikrobiotsku aktivnost i povoljno utiče na klijanje i razvoj prirodnog podmlatka.

\section{Literatura - References}

ALIKALFIĆ, F. 1970: Izbojna snaga nekih lišćara. Savez inžinjera i tehničara šumarstva i industrije za preradu drveta, Sarajevo.

ALIKALFIĆ, F. 1998: Lisnik i lisničke šume u Bosni i Hercegovini. Šumarski fakultet u Sarajevu, Sarajevo.

BEUS, V. 1984: Vertikalno raščlanjenje šuma u svjetlu odnosa realne i primarne vegetacije u Jugoslaviji. ANUBiH, Radovi LXXVI, knj. 23, Sarajevo: 23-32.

BOLTE, A., 1999a: Canopy thinning, light climate and distribution of Calamagrostis epigejos (L.) ROTH in a Scots pine forest (Pinus sylvestris L.). Verhandl. d. Ges. f. Ökologie 29, Spektrum Akademischer Verlag Heidelberg: 9-18.

BOLte, A.; LeßneR, C.; MülleR, J.; KALLWEit, R., 2001: Zur Rolle der Bodenvegetation im Stoff- und Wasserhaushalt von Kiefernökosystemen - Level II-Untersuchungen in Brandenburg. Beiträge für Forstwirtschaft und Landschaftsökologie 35: 26-29.

BurlicA, C.; StefaNOVIC, V., 1988: Neki ekoloski problemi rekonstrukcije degradiranih Šuma. Šumarstsvo i prerada drveta 1-3: 21-26.

BuRSCHEL, P., Huss, J. 1997: Grundriss des Waldbaus: ein Leitfaden für Studium und Praxis - Parey, 485 S., Berlin. 
DoHRENBUSCH, A., 2002: Vzmozhnosti sa prevrschchane na niskostbleni gori $\mathrm{v}$ produktivni gorskostopanski formi, "Nazionalno sveschchanije po stopanisvane na izdnkovite dbovi gori. Burgas, 8. - 10. Mai 2002. Tagungsbericht: 41-47.

ĐIKIĆ, S. 1960: O sprovođenju meliorativnih radova u šikarama (diskusija). Narodni šumar 5-6, Sarajevo.

ĐiKIĆ, S., KolaKović, R.. 1965: Osnovi za proizvodno ekološku klasifikaciju zapustenih i degradiranih panjaca u Bosni i Hercegovini. Radovi Šumarskog fakulteta i Instituta za Šumarstvo Sarajevo, Posebno izdanje

Ellenberg, H. (1996): Vegetation Mitteleuropas mit den Alpen - Ulmer, 1095 S., Stuttgart.

GARDINER, E.S.; HELMIG, L.M., 1997: Development of water oak stump sprouts under a partial overstory. New Forests 14: 55-62.

GARELKOV, D., 1979: The regeneration process in the beech forests of the Stara Planina. Gorskostopanska Nauka (Sofia) 16: 12-33.

GeIGER, R. 1981: Das Klima der bodennahen Luftschiht. Braunschweig.

HÖLSCHER, D.; SCHADE, E.; LeUSCHNER, CH., 2001: Effects of coppicing in temperate deciduos forests on ecosystem nutrient pools and soil ferility. Basic Appl. Ecol. 2: 155-164.

JoHANNSON, T., 1986: Development of suckers by two-year-old birch (Betula pendula Roth) at different temperatures and light intensities. Scand. J. For. Res. 1: 17-26.

JohANNSON, T., 1987: Development of stump suckers by Betula pubescens at different light intensities. Scand. J. For. Res. 2: 77-83.

JoHANNSON, T., 1991: Sprouting ability of two-year-old Betula pendula stumps exposed to different light intensities during five years. Scand. J. For. Res. 6: 509-518.

Kolaković, R., 1960: Problem melioracije šikara i niskih šuma. Narodni šumar, posebno izdanje, Sarajevo.

KoRIČIĆ, Š. 2005: Biološki, ekološki i ekonomski pokazatelji uspješnosti prorjeda u panjačama bukve. Doktorska disertacija. 220 S. Sarajevo.

KRSTIĆ, M. (2002): Melioracija degradiranih šuma.Glasnik Šumarskog fakulteta, br. 80-81, str.75-85.. Šumarski fakultet. Beograd.

KRSTIĆ, M. 2003: Program za simulaciju uzgojnih radova (SiMS). Zbornik radova, Simpozijum: Perspektive razvoja šumarstva, Šumarski fakultet Univerziteta u Banja Luci, str. 97-111.

Krstić, M., Stojanović, LJ., Aleksić, P., Radovanović, T. 2004: Predlog odgovarajućih uzgojnih zahvata u izdanačkim bukovim šumama na Jasterbcu. Šumarstvo. Šumarski fakultet Beograd. Br.4. str.1-18.

Krstić, M., Koprivica, M., Rakonjac, LJ., MiliJaŠEVIĆ, T., Popović, Z., Danilović, M., KoŠANIN, O., LAVADINOVIĆ, V., 2005: Izdanačke bukove šume severoistočne Srbije. Šumarski fakultet Beograd, Institut za šumarstvo. Beograd.

LeSSEL-DummeL, A, 1979: Disposition von Kiefernbeständen gegenüber Schneebruch. Allg. Forstzeitung 34: 1281-1282. 
MATIĆ, S. 1987: Savjetovanje o panjačama, Sarajevo, 22.10 .1986 - Gospodarski zahvati u panjačama kao mjera povećanja produktivnosti i stabilnosti šuma, Šumarski list 3-4, str. 143148, Zagreb.

MATIĆ, S., ANIĆ, I., ORŠANIĆ, M. (2003): Njega bukovih panjača; Obnova bukovih panjača. Monografija: Obična bukva u Hrvatskoj, ed. Matić, S., Zagreb.

MATIĆ, V., ET AL., 1971: Stanje šuma u BiH prema inventuri šuma na velikim površinama u periodu 1964-1968. god. Sarajevo, Šumarski fakultet i Institut za šumarstvo u Sarajevu, posebno izdanje broj 7.

MEKIĆ, F. 1998: Rasadnci i nasadi. Šumarski fakultet u Sarajevu, Svjetlost-Fojnica, 600 S., Fojnica.

MülleR, J.; Bolte, A.; BeCK, W.; ANDERS, S., 1998: Bodenvegetation und Wasserhaushalt von Kiefernforstökosystemen (Pinus sylvestris L.). Verhandl. d. Ges. f. Ökologie 28, G. Fischer Verlag Stuttgart: 407-414.

MülleR, J.; BOLTE A., 2002: Verdunstung der Bodenvegetation verbreiteter Vegetationsformen der Kiefer in Abhängigkeit von der Art und ihrem Deckungsgrad. In: Anders, S.; Beck, W.; Bolte, A.; Hofmann, G.; Jenssen, M.; Krakau, U.-K.; MÜLLER, J.: Ökologie und Vegetation der Wälder Nordostdeutschlands. Remagen-Ow., Verlag Dr. Kessel: 99-112.

NAGel, J., Duda, H, Hansen, J. 2006: ForestSimulator BWINPro 7. Version 2006, NFV Goettinen.

PATAKY, LJ. 1956: Melioracija šikara i drugih oblika degradiranih niskih šuma; udžbenik; Institut za šumarstvo i drvnu industriju NR BiH, Sarajevo.

PATKY, LJ. 1960: Savremene metode melioracije degradiranih šuma i šikara. Manuskript, Poljoprivredno-šumarska komora NRBiH Sektor za šumarstvo, 37 S., Sarajevo.

PETRI, G., 1976: Schneedruckschäden vom März 1975 in Kiefernjungbeständen der nordbadischen Rheinebene. AF 31: 1048-1049.

PINTARIĆ, K. 2002: Problem prevođenja izdanačkih šuma bukve (Fagus sylvatica L.) u visoku šumu, Šumarski list 3-4, str-119-128, Zagreb.

Ротт, R. 1985: Vegetationsgeschichtliche und pflanzensoziologische Untersuchungenzur Niederwaldwirtschaft in Westfalen - Abhandlungen aus dem Westfälischen Museum für Naturkunde, 47, 4: $75 \mathrm{~S}$.

RYDBERG, D., 2000: Initial sprouting, growth and mortality of European aspen and birch after selective coppicing in central Sweden. For. Ecol. Mange. 130: 27-35.

RoehRIG, E., BARTSCH, N., VON LUEPKE, B. 2006: Waldbau auf oekologischer Grundlage. 7., vollstaendig aktualisierte, Auflage, Verlag Eugen Ulmer, 479 S., Stuttgart.

SCHAEDELIN, W. 1942: Die Auslesedurchforstung als Erziehungsbetrieb hoehster Wertleistung. Bern (Haupt).

SCHERZINGER, W. 1996: Naturschutz im Wald: Qualitätsziele einer dynamischen Waldentwicklung - Ulmer, 447 S., Stuttgart. 
Stojanović, O., BurlicA, Č., IZetbegović, S., KoprivicA, M., LAZAREV, V., LUteršEK, D., Mekić, F., PAVliČ, J., PINTARIĆ, K., Stefanović, 1986 a: Ekološko-proizvodne karakteristike (proizvodni potencijal), dugoročni ciljevi i mogućnosti proizvodnje drveta, na staništima izdanačkih šuma bukve u SR BiH. Šumarski fakultet, naučno-istraživački projekat, str.1-120., Sarajevo.

Stojanović, O., ĐurĐeVić, J., Koprivica, M., LazAReV, V., LUTERŠEK, D., MEKIĆ, F., PAVlič, J., PINTARIĆ, K., Stefanović, V., VRLJIČAK, J. 1986 a: Ekološko-proizvodne karakteristike (proizvodni potencijal), dugoročni ciljevi i mogućnosti proizvodnje drveta, na staništima izdanačkih šuma hrasta kitnjaka u SR BiH. Šumarski fakultet, naučnoistraživački projekat, str.1-99., Sarajevo.

VIŠNJIĆ, Ć. 2006: Aufforstung von sommertrockenen Standorten mit heimischen Baumarten in Bosnien, Dissertation, Goettingen.

VUKMIROVIĆ, V., Stojanović, O. 1966: Zapremina i zapreminski prirast šikara bukve, hrasta, graba i jasena u Bosni. Radovi Šumarskog fakulteta i Instituta za šumarstvo u Sarajevu. Knjiga 11. sv. 4.

YoshidA, T.; KAMITANI, T., 1997: The stand dynamics of a mixed coppice forest of shade-tolerant and intermediate species. For. Ecol. Mange. 95: 35-43.

\section{Sammary - Sažetak}

Coppice beech forests in Bosnia and Herzegovina cover 351.000 hectares and occur mainly in very gut soil condition. The high productive potential of the sites is not adequately utilized. Therefore, in the second half of last century worked on conversion in high forest. All methods were based on direct and indirect conversion. Researches show that the direct conversion of beech coppice in high forest should be avoided. Indirect conversion with optimization of tending operations can give good results. For beech coppice forests younger than 60 years recommended selective thinning with selecting 200-300 trees which are gut spread by area. For older than 60 year beech coppice forests they recommended uniform system. For better orientation for the way of conversion coppice forests in high forests it is need to know stand condition of coppice forests. Of stand and structural indicators are the most important: age of coppice forests, stand condition of beech coppice forests, generation of shoots, number of seed trees, natural regenerations. Beside them is necessary to know the degree of canopy. Light as an environmental factor is of decisive importance for microbiological activity in soil, humus decomposition and occurrence of natural regenerations. Beech coppice forest at the site Musici, based on analysis of these factors, there are optimal conditions for starting conversions in high forest. It should carry out selective thinning with cutting bad shoots from stump.

Beech coppice forest at the site Musici was formed cutting high forest and shoots at upper level belong to the first generation. Therefore, it should be treated with a high forest. The most number of shoots are at the lowest diameter classes and that number is reduced to a larger diameter classes and a structure similar of uneven-aged type of forest or usually termed "selection forest". 
In the beech coppice forest at the site Musici near Sarajevo, there are the most of stump with one or two shoots. Maximal numbers of shoots from stump are 10, and there are only two stumps with 10 shoots.

On two experimental plots were carried out in two ways thinning as follows: selective thinning and selective thinning with cutting of bad shoots from stump. By selective thinning intensity of cutting by the number of trees was $11,5 \%$ and by selective thinning and cutting of bad shoots $32,8 \%$. Intensity of logging by tree basal area was by selective thinning $26,9 \%$ and by selective thinning and cutting of bad shoots from stump 29,8\%.

Based on the above we can conclude, that during work on the thinning it is desirable addition of selective thinning, reduced number of bad shoots from stump. So it reduces competition for water and minerals for selected trees in beech coppice forest. In addition, the more light reaches beech coppice forests which improves the microbiological activity and occurrence of natural regenerations 